DOI: 10.35757/RPN.2012.20.04

Joanna Szymoniczek

\title{
POLSKA OPINIA PUBLICZNA WOBEC NIEMIEC I WYDARZEŃ 1968 ROKU W NIEMCZECH
}

Niniejsze opracowanie jest próbą przedstawienia reakcji polskiego społeczeństwa i polskiej opinii publicznej na wydarzenia 1968 roku w Niemczech. W tym celu dokonałam przeglądu artykułów prasowych, m.in. pod kątem częstotliwości ich pojawiania się, sposobu przedstawiania wydarzeń, opinii i komentarzy, tytułowania relacji i zamieszczania zdjęć, a także proporcji tych artykułów do artykułów podejmujących inne tematy, zamieszczonych w najpopularniejszych dziennikach tamtego okresu, takich jak „Dziennik Ludowy”, "Gazeta Krakowska”, „Gazeta Robotnicza”, ,Ilustrowany Kurier Polski”, ,Trybuna Ludu” „Trybuna Robotnicza”, "Życie Warszawy”, tygodnikach, m.in. „Polityka”, „Forum” i „Tygodnik Powszechny” oraz miesięcznikach, m.in. "Szpilki”. $\mathrm{W}$ ramach prowadzonych badań zapoznałam się także $\mathrm{z}$ programami i audycjami telewizyjnymi oraz radiowymi, w tym przede wszystkim z serwisami informacyjnymi Telewizji Polskiej i Polskiego Radia. Niestety wyniki kwerendy przeprowadzonej w tych dwóch instytucjach nie są zadowalające. Zbiory Archiwum Telewizji Polskiej, podobnie jak Polskiego Radia, są niekompletne. Mimo intensywnej kwerendy udało się odnaleźć niewiele materiałów dotyczących Niemiec w 1968 roku. Natomiast w programach i audycjach informacyjnych, takich jak 7 dni w kraju i na świecie, temat Niemiec pojawia się, co może budzić pewne zaskoczenie, sporadycznie. Na podstawie dostępnych informacji niemożliwe jest ustalenie, jaki fragment stanowią zachowane materiały, 
czego brakuje itp. Dodatkowo w części materiałów nie ma informacji bibliograficznych, takich jak rok i miejsce produkcji, nazwisko reżysera, scenarzysty, producenta, a czasem nawet tytułu. Stąd informacje pochodzące $\mathrm{z}$ tych dwóch archiwów potraktowane zostały jako uzupełniające, a za najważniejszą uznano analizę tytułów prasowych.

Głównym celem badań była próba pokazania, w jaki sposób potrzeby polityki zagranicznej i wewnętrznej autorytarnego państwa, jakim była Polska Rzeczpospolita Ludowa, prowadziły do deformacji obrazu wydarzeń 1968 roku, oraz odpowiedzi na pytania: czy polska opinia publiczna miała w 1968 roku możliwość artykulacji swojego zdania, opinii, jak obraz w prasie był manipulowany, jak społeczeństwo polskie reagowało na wydarzenia 1968 roku w Niemczech? Czy wydarzenia 1968 roku w Niemczech miały swoją kontynuację w polskich mediach? Czy, a jeśli tak, to w jaki sposób i przy jakiej okazji odwoływano się w kolejnych latach do tych wydarzeń?

Chciałabym jednak rozpocząć od kilku uwag na temat ogólnej sytuacji mediów w Polskiej Rzeczpospolitej Ludowej oraz oficjalnej cenzury.

\section{Media w Polskiej Rzeczpospolitej Ludowej}

System medialny ukształtowany w Polsce po II wojnie światowej podporządkowano praktyce politycznej. Rządząca partia komunistyczna traktowała początkowo radio i prasę, a potem także telewizję jako jeden z najważniejszych instrumentów sprawowania władzy i sterowania procesami społecznymi ${ }^{1}$. Reżim dokładnie określał, o jakich tematach należy pisać, a o jakich nie, jakim problemom mogą być poświęcone ukazujące się artykuły, a które można jedynie zasygnalizować petitem $\mathrm{w}$ rubryce o wydarzeniach na świecie, który temat zasługuje na reportaż, z kim można przeprowadzić wywiad, czyje zdjęcie lub jaki materiał filmowy można przedstawić czytelnikowi czy słuchaczowi. Wszystkie przekazywane treści poddawane były wnikliwej cenzurze. Tylko tak przygotowane tematy uznawano za jedynie słuszne i prawdziwe ${ }^{2}$. Tym samym istniały daleko idące możliwości kreowania dla odbiorcy obra-

\footnotetext{
1 M. Iłowiecki: Media, władza, świadomość społeczna, Łódź 1999, s. 39-43.

2 M. Karpiński: Zapis na cenzurę, Warszawa 1981, s. 6.
} 
zu świata, który dość istotnie różnił się lub nawet całkowicie odbiegał od rzeczywistości. Media nie odgrywały przypisywanej im od początku istnienia roli wyraziciela opinii i nastrojów społecznych, stając się tylko jednokierunkowym przekaźnikiem treści „od władzy do mas”3.

Ze względu na omawiany temat należy zwrócić uwagę na kilka działań podjętych wobec prasy w Polsce. Przede wszystkim władza ograniczyła dostęp do innych, poza Polską Agencją Prasową (PAP), źródeł informacji, $\mathrm{w}$ tym zakazano prowadzenia $\mathrm{w}$ redakcjach nasłuchu radiowego z zagranicy. Sama PAP miała natomiast ograniczone możliwości działania. Aby móc realizować wspomniane już wytyczne władz, zwiększono liczbę jej korespondentów w krajach demokracji ludowej, ale $\mathrm{w}$ pozostałych, przede wszystkim w Stanach Zjednoczonych i państwach Europy Zachodniej, nie tylko drastycznie zmniejszono obsadę, lecz także zlikwidowano część placówek. Redakcjom ograniczono prawo do korzystania z amerykańskich i zachodnioeuropejskich serwisów fotograficznych, argumentując ten krok koniecznością płacenia za prawa do publikacji wysokich honorariów i w dodatku w dewizach. Konieczność korzystania ze zdjęć rodzimych fotografów, ewentualnie $\mathrm{z}$ „zaprzyjaźnionych" państw, była jedną z przyczyn powtarzania się tych samych zdjęć nie tylko w kolejnych artykułach, ale i tytułach prasowych. Redakcjom polecono także dbanie o proporcję materiałów informacyjnych na korzyść doniesień z krajów socjalistycznych oraz wydano walkę tzw. amerykanizmom, czyli „,bezkrytycznym zachwytom dla nauki i techniki amerykańskiej". W efekcie często nawet najważniejsze wydarzenia z krajów Europy Zachodniej i Stanów Zjednoczonych przegrywały z mało znaczącymi ze Związku Radzieckiego, samej Polski czy innych państw bloku wschodniego ${ }^{4}$.

Prawda była relatywizowana. Na porządku dziennym było operowanie półprawdami czy pisanie nieprawdy, co nie było uznawane za naganne, lecz nawet za pożądane, jeśli tylko służyło sprawie. Świat przedstawiano w tonacji czarno-białej, posługując się spójnym wewnętrznie systemem stereotypów i dobierając fakty i argumenty w sposób selek-

3 A. Kozieł: Prasa w latach 1944-1989, w: Prasa, radio i telewizja w Polsce. Zarys dziejów, Warszawa 2001, s. 143.

4 W. Sonczyk: Media w Polsce. Zarys problematyki, Warszawa 1999, s. 28. 
tywny, pod z góry przyjętą tezę. Za pomocą stereotypów prasa utrwalała wiele mitów. W tekstach widoczny był brak jakichkolwiek polemik oraz jednostronność. Język tekstów i artykułów był w większości przypadków sztampowy, pełen sloganów i propagandowej nowomowy. Główne tematy tamtych lat to podsycanie atmosfery zagrożenia (teksty dotyczące imperializmu, zimnej wojny, głównych wrogów Polski, czyli Stanów Zjednoczonych i Niemiec Zachodnich, agentów wroga i sabotażystów, zachęcające do czujności i szukania wrogów), atakowanie Kościoła, gloryfikowanie wszystkiego, co radzieckie, mobilizacja do wypełniania planów produkcyjnych, wyścig pracy, agitacja na rzecz kolektywizacji wsi ${ }^{5}$. Dotyczyło to wszystkich rodzajów periodyków, które ukazywały się w tym czasie, choć oczywiście ze względu na charakter każdego występowały określone różnice. I tak dzienniki partyjne, przeznaczone dla aktywu partyjnego, przesiąknięte były propagandą, agitacją na rzecz partii i systemu, dzienniki czytelnikowskie, mające popularniejszy charakter, cechowały się mniej „nachalną” propaganda, spokojniejszym i lepszym stylem redagowania, zaś w popołudniówkach przeznaczonych dla masowego odbiorcy dominowała zazwyczaj lekka forma, żywy język, dynamiczna grafika i przewaga treści rozrywkowych ${ }^{6}$.

Zmiana sytuacji prasy, związana z „odwilżą" po śmierci Stalina, była krótkotrwała. Uatrakcyjniano wprawdzie wówczas treści prasowe, starano się zróżnicować i wzbogacić formy wypowiedzi oraz język, tak aby być bliżej ludzi i ich spraw. W efekcie w wielu tytułach $z$ jednej strony podejmowane są coraz poważniejsze tematy, z drugiej pojawiały się recenzje i obrazy zachodniej kultury i mody, w więc teksty dotyczące amerykańskiej muzyki (przede wszystkim jazzu), zachodniego stylu życia, mody, filmu itp. Jednak tuż po VIII Plenum w październiku 1956 roku nastąpiło „sprowadzenie prasy na właściwe miejsce”, co polegało m.in. na znaczących zmianach personalnych $\mathrm{w}$ redakcjach, ostrej cenzurze, braku swobody artystycznej i dziennikarskiej, jak i zmniejszeniu liczby tytułów prasowych. Kolejna weryfikacja środowiska dziennikarskiego nastąpiła po Marcu 1968 roku.

\footnotetext{
5 R. Gluza (red.): Media w Polsce w XX wieku, Poznań 1999, s. 32.

6 A.M. Dereń, A. Kudłaszyk: Polskie prawo prasowe, w: A. Kudłaszyk, A. Małkiewicz, R. Karpiński (red.): Mass media w systemie komunikacji społecznej w Polsce, Wrocław 1995, s. 45-49.
} 


\section{Cenzura w Polskiej Rzeczpospolitej Ludowej}

Cenzura kreuje z góry założony wizerunek wydarzeń, blokuje informacje i treści niezgodne $\mathrm{z}$ interesami władzy i zastępuje je treściami propagandowymi. Stanowi więc podstawową strukturę $\mathrm{w}$ państwie niedemokratycznym, pozwala bowiem na legitymizację władzy. Jeśli zmanipulowany obraz jest jedynym, jaki jest dostępny społeczeństwu, to opinie i sądy kształtują się na jego podstawie. Stąd kontrola nad mediami daje nieograniczone możliwości manipulacji obrazem rzeczywistości.

W Polsce w latach 1944-1990 istniał nadzór nad informacjami podawanymi przez prasę, publikacje naukowe, kulturalne i widowiska do wiadomości publicznej. Początkowo kontrolę nad cenzurą sprawował minister spraw wewnętrznych. Jednak już 5 lipca 1946 roku na podstawie dekretu, sprzecznego z prawem prasowym z 1938 roku, utworzono Główny Urząd Kontroli Prasy, Publikacji i Widowisk (GUKPPiW), który w lipcu 1981 roku został przemianowany na Główny Urząd Kontroli Publikacji i Widowisk ${ }^{7}$ podlegający Prezesowi Rady Ministrów. Urząd dzielił się na terenowe Urzędy Kontroli Prasy, Publikacji i Widowisk. Dyrektor GUKPPiW powoływany był przez Radę Ministrów na wniosek Prezesa Rady Ministrów, sam zaś Urząd finansowany był z budżetu Prezydium Rady Ministrów. Zadania GUKPPiW określone zostały w artykule drugim wspomnianego dekretu w sposób następujący:

nadzór nad prasa, publikacjami i widowiskami w zakresie, przewidzianym w szczególnych przepisach prawnych, kontrola rozpowszechniania wszelkiego rodzaju utworów za pomocą druku, obrazu i żywego słowa; kontrola ta miała na celu zapobieżenie:

- godzeniu w ustrój Państwa Polskiego,

- ujawnianiu tajemnic państwowych,

- naruszaniu międzynarodowych stosunków Państwa Polskiego,

- naruszaniu prawa lub dobrych obyczajów,

- wprowadzaniu w błąd opinii publicznej poprzez podawanie wiadomości niezgodnych z rzeczywistością.

7 Archiwum Akt Nowych (dalej: AAN), GUKPPiW, sygn. 2813, Dekret z dn. 5 sierpnia 1946 r. o utworzeniu Głównego Urzędu Kontroli Prasy, Publikacji i Widowisk, s. 24. 
Urząd zajmował się kontrolą wszelkich publikacji, przedstawień teatralnych, audycji radiowych i telewizyjnych, wystąpień sejmowych, a nawet różnego rodzaju instrukcji obsługi maszyn, etykiet na towarach, pod kątem treści niezgodnych z oficjalną linią propagandy. W latach 1945-1980 ingerencje cenzury w teksty drukowane nie były w ogóle oznaczane ${ }^{8}$.

Dekret o utworzeniu Głównego Urzędu Kontroli Prasy, Publikacji i Widowisk stał w sprzeczności z Ustawą Konstytucyjną z dnia 19 lutego 1947 roku o ustroju i zakresie działania najwyższych organów Rzeczpospolitej Polskiej, czyli tzw. Małą Konstytucją9 oraz z Konstytucją Polskiej Rzeczpospolitej Ludowej uchwaloną przez Sejm Ustawodawczy w dniu 22 lipca 1952 roku $^{10}$, która gwarantowała swobody obywatelskie. W artykule 71 zapisano bowiem:

Polska Rzeczpospolita Ludowa zapewnia obywatelom wolność słowa, druku, zgromadzeń i wieców, pochodów i manifestacji. Urzeczywistnianiu tej wolności służy oddanie do użytku ludu pracującego i jego organizacji drukarni, zasobów papieru, gmachów publicznych i sal, środków łączności, radia oraz innych niezbędnych środków materialnych.

Dopiero w 1981 roku wprowadzono możliwość odwoływania się od decyzji GUKPiW do Naczelnego Sądu Administracyjnego. Sam dekret został uchylony 1 lipca 1984 roku, a w 1990 roku zniesiona została cenzura prewencyjna.

\section{Niemcy Zachodnie w prasie polskiej w 1968 roku}

Republika Federalna Niemiec była w całym okresie PRL, obok Stanów Zjednoczonych, negatywnym bohaterem. Prasa zamieszczała sporo przypomnień o II wojnie światowej, kolejnych rocznicach konkretnych zbrodni, bez przerwy przypominając ich skalę, zniszczenia i liczbę ofiar. $\mathrm{Na}$ tym tle nieustannie podkreślano bohaterstwo i rolę Związku Radzieckiego $\mathrm{w}$ pokonaniu faszyzmu. $\mathrm{W}$ tekstach często nawiązywano

8 AAN, GUKPPiW, sygn. 829, Przeglądy interwencji i przeoczeń w publikacjach periodycznych, nieperiodycznych, drukach ulotnych itp., s. 118-120.

9 Dziennik Ustaw z 1947 roku, nr 18, poz. 71.

${ }^{10}$ Dziennik Ustaw z 1952 roku, nr 33, poz. 232. 
do rewizjonistycznej polityki powojennej RFN. Stąd Niemcy Zachodnie prezentowane było jako państwo militarystyczne, pragnące broni atomowej i rakiet, naciskające partnerów zachodnich na zbrojenia i blokujące rozbrojenie ${ }^{11}$. To także RFN, razem z Izraelem i Stanami Zjednoczonymi, doprowadzała do eskalacji napięcia w związku z jej postawą wobec konfliktu w Wietnamie i na Bliskim Wschodzie. W RFN zwalczano lewicę, policja prześladowała Komunistyczną Partię Niemiec (Kommunistische Partei Deutschlands - KPD), a na sile zyskiwali naziści (Narodowa Partia Niemiec, Nationaldemokratische Partei Deutschlands - NPD) ${ }^{12}$. Polska nie mogła mieć do niej zaufania, szczególnie wobec obsesji Bonn na punkcie zjednoczenia Niemiec.

W związku z ważnymi, zajmującymi i dającymi się wykorzystać propagandowo wydarzeniami w Stanach Zjednoczonych (m.in. wojna w Wietnamie, zabójstwo Martina Lutera Kinga i Roberta Kennedy'ego), jak i wspomnianymi już wytycznymi zmuszającymi redakcje do starannego dbania o odpowiednie, korzystne dla państw socjalistycznych proporcje ukazujących się tekstów, temat RFN nie pojawiał się tak często w 1968 roku, jak można byłoby się tego spodziewać. Nie oznacza to jednak, że w tym roku temat RFN nie był wcale podejmowany. Pojawiające się sporadycznie teksty dotyczące sytuacji w RFN w związku z falą protestów i demonstracji wpisywały się w cykl artykułów dotyczących wydarzeń w Stanach Zjednoczonych, Francji, Wielkiej Brytanii, Belgii czy Włoszech, w których zazwyczaj nie skupiano się na jednostkowych wydarzeniach $w$ poszczególnych państwach, tylko traktowano je razem, jako państwa zachodnie. Z tekstów tych wyłaniał się obraz państw objętych falą ruchów społecznych, protestów przeciwko wojnie w Wietnamie $^{13}$, walkami ulicznymi, napięciami w szkołach i na uczelniach, strajkami młodzieży, która domagała się zmian w regulaminach nauczania i studiowania, wzrostu nakładów na oświatę czy reformy systemu oświatowego ${ }^{14}$. Dostrzegano, że lata sześćdziesiąte zapoczątkowały w świecie zachodnim nowe zjawiska społeczne i obyczajowe, których

\footnotetext{
${ }^{11}$ Z. Bagiński: Bundesmarine i rakiety, „Polityka”, 24 lutego 1968, nr 8, s. 10.

${ }^{12}$ H. Harting: NPD wyjaśnia..., „Polityka”, 20 czerwca 1968, nr 16, s. 12.

${ }_{13}$ Archiwum Telewizji Polskiej (dalej: A TVP), sygn. Zarch. 68201, Demonstracje studentów w Japonii, USA i Korei przeciwko wojnie i rasizmowi.

${ }^{14}$ A TVP, sygn. F 913, Przeglad roku 1968.
} 
podłożem były przemiany kulturowe, frustracje studentów i absolwentów wyższych uczelni poszukujących pracy oraz naiwny anarchizm, będący reakcją na dobrobyt, porządek i brak poważniejszych problemów. Zjawiska te i przeobrażenia w obyczajowości oceniane były w polskich mediach negatywnie ${ }^{15}$.

Dopiero zamach na Rudiego Dutschkego spowodował, że Niemcom zaczęto poświęcać osobne teksty. Najpierw, 12 kwietnia 1968 roku, pojawiły się informacje dotyczące samego zamachu oraz przywódcy Socjalistycznego Związku Studentów Niemieckich (Sozialistischer Deutscher Studentenbund - SDS): „Stany Zjednoczone nie mają monopolu na mord polityczny. W Berlinie zachodnim dokonano zamachu na Rudi Dutschkego, przywódcę Socjalistycznego Związku Studentów Niemiec$\mathrm{kich}^{\prime 16}$, w których dokładnie, emocjonalnie i propagandowo relacjonowano to, co się działo w RFN: masowy sprzeciw młodzieży, brutalne metody policji, głusi na argumenty niemieccy politycy. Przytaczano wypowiedzi polityków światowych, sprzeciwiających się takiej polityce Bonn. Następnie prasa polska skupiła się na uchwalonych 30 maja 1968 roku ustawach wyjątkowych, będących reakcją Bundestagu na masowe demonstracje, w których wzięło udział kilkadziesiąt tysięcy osób w 27 miastach niemieckich oraz niepokoje społeczne. Ustawy wyjątkowe, ograniczające wolności obywatelskie, miały umożliwić władzy skuteczniejszą walkę z zamieszkami. Powtarzanie haseł protestujących, takich jak „Nie chcemy więcej roku 1933” czy „W obronie demokracji”, jednakże często $\mathrm{w}$ oderwaniu od relacjonowania protestów, stwarzało dla czytelnika wrażenie, że nie jest to stanowisko protestujących w RFN, tylko innych, zagrożonych, społeczeństw, obawiających się, że przygotowywane w RFN ustawy wyjątkowe wprowadzą Dyktaturę w majestacie prawa. Artykuły wzmacniał ton tekstów: alarmujący, często histeryczny, nie brakowało wiele mówiących tytułów, zazwyczaj odnoszących się do II wojny światowej i ciągłego zagrożenia dla Polski, jak i innych państw bloku wschodniego, ze strony RFN.

${ }^{15}$ P.D. Zimmerman: Wszystko dozwolone, „Forum”, 23 grudnia 1967, nr 52/53, s. 25-27.

16 „Polityka”, 20 kwietnia 1968, nr 16; Archiwum Polskiego Radia (dalej: A PR), sygn. 3211 poz. 1, 7 dni w kraju i na świecie z 14 kwietnia 1968 roku; Strzały na Kurfürstendamm, „Forum”, 21 kwietnia 1968, nr 16, s. 5. 

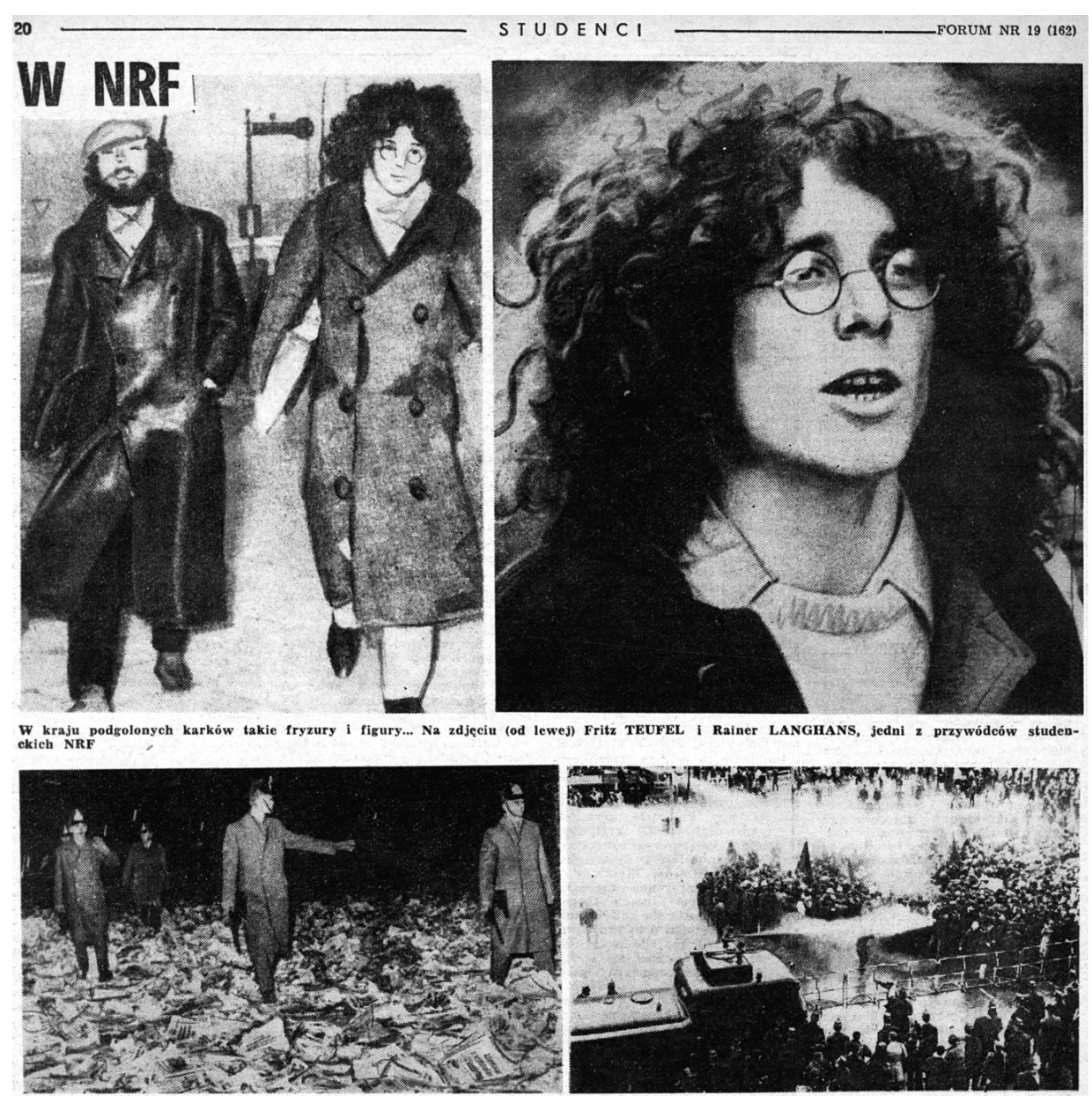

Tak rozprawiano sie z prasa SPRINGERA (o tej osobistości i jej koncernie

Armaty wodne w akeji (specjalna broń antydemonstracyjna)
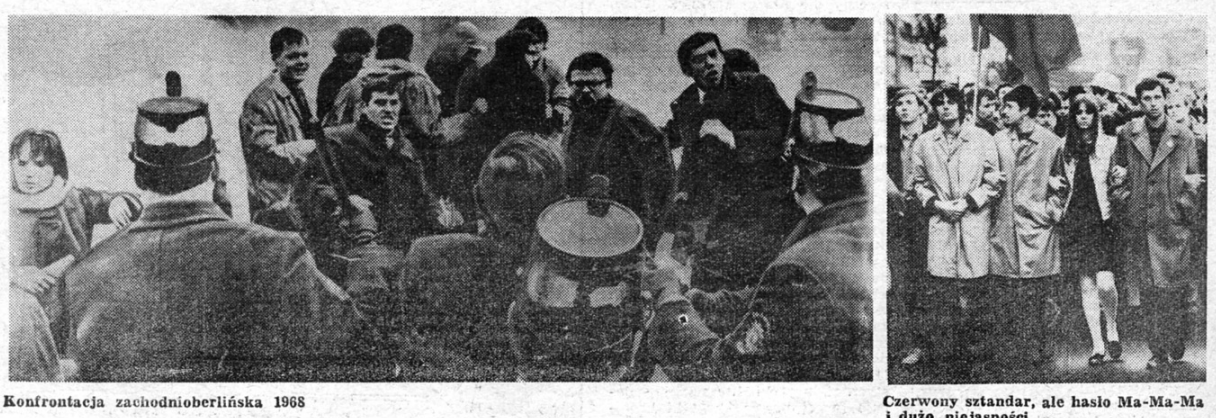

Źródło: „Forum” 1969, nr 19(162). 
Tymczasem pojawiły się też artykuły, które miały pokazać, że wiosna 1968 roku w Niemczech jest nie mniej gorąca niż w innych państwach zachodnich, a także trochę przybliżające postać Rudiego Dutschkego, skupiając się na jego roli w Radzie SDS-u oraz organizacji demonstracji, podczas których studenci domagali się reformy szkolnictwa wyższego, skupieni wokół tzw. Opozycji Pozaparlamentarnej (Außerparlamentarische Opposition - APO) występowali przeciw Wielkiej Koalicji, ustawom wyjątkowym i protestowali przeciw wojnie w Wietnamie. Lakonicznie przypominano też Benno Ohnesorga, studenta, który 2 czerwca 1967 roku został zastrzelony przez policjanta Karla Heinza Kurrasa podczas demonstracji przeciw wizycie w Berlinie Zachodnim szacha Iranu Mohammada Rezy Pahlawiego. Przypominano udział Rudiego Dutschkego w organizacji tzw. siedzących blokad, które miały wymusić ustąpienie osób odpowiedzialnych za akcję policyjna, a także wywłaszczyć Axela Springera („Enteignet Springer” - „wywłaszczyć Springera - hasło propagandowe protestujących), którego gazety, zwłaszcza „Bilda”, ze względu na sposób relacjonowania wydarzeń studenci obarczyli odpowiedzialnością za śmierć Ohnesorga. Teksty te były jednak zdecydowanie spóźnione, zbyt pobieżne i lakoniczne, zwłaszcza wobec informacji dotyczących innych państw zachodnich. Należałoby podkreślić, że $\mathrm{w}$ żadnym $\mathrm{z}$ dziewiętnastu analizowanych tytułów prasy codziennej nie znalazło się nawet jedno zdjęcie przywódcy Socjalistycznego Związku Studentów Niemieckich ${ }^{17}$.

Prasa polska dość szybko straciła jednak zainteresowanie wydarzeniami w Niemczech i osobą Rudiego Dutschkego. Z prasy codziennej nie dało się nawet wywnioskować, czy przeżył on zamach. Po kilku komunikatach dotyczących jego stanu zdrowia bezpośrednio po zamachu oraz informacjach dotyczących tego, co się dzieje w Niemczech, temat $\mathrm{w}$ zasadzie znikł z łamów gazet. Tymczasem w całych Niemczech nie ustawały zamieszki, w samym Berlinie około pięciotysięczny tłum próbował szturmować wieżowiec będący siedzibą wydawnictwa Axela Springera, właściciela „Bilda”, gazety, którą obarczono odpowiedzialnością za w konsekwencji „morderczą” propagandę i nagonkę na SDS,

${ }^{17}$ Strategia Blutwurstu, „Polityka”, 2 września 1967, nr 35; Lewica NRF, „Polityka”, 27 kwietnia 1968, nr 17; Narasta kryzys, "Gazeta Krakowska”, 30 maja 1968, s. 1-2. 
Dutschkego i jego towarzyszy. Uwagę polskich mediów w tym czasie jednak znów przykuwają wydarzenia w Stanach Zjednoczonych i we Francji; przede wszystkim zabójstwo Martina L. Kinga i Roberta Kennedy'ego oraz fala protestów we Francji1 ${ }^{18}$.

\section{Nawiązania w polskiej prasie do wydarzeń roku 1968 w Niemczech}

Wydarzenia roku 1968 w Niemczech, jak już wyjaśniałam, nie cieszyły się większym zainteresowaniem mediów polskich. Nie inaczej było w latach następnych. Odniesień do roku 1968 w Niemczech w polskiej prasie jest niewiele. Przypominane są one w zasadzie tylko przy okazji krytykowania zachodniego stylu życia i "upadku moralnego Zachodu”, relacjonowania wydarzeń związanych $\mathrm{z}$ terroryzmem $\mathrm{w}$ Niemczech, zwłaszcza działalności RAF-u (Rote Armee Fraktion - Frakcja Czerwonej Armii) w latach siedemdziesiątych oraz mianowania Joschki Fischera na stanowisko ministra spraw zagranicznych RFN w 1998 roku. Ale nawet jeśli były już przywoływane, to tylko w niewielkim zakresie, mimochodem, bez jakiś poważniejszych analiz czy wniosków.

\section{„Upadek moralny Zachodu”}

Skupianie się $\mathrm{w}$ polskich mediach na problemach Zachodu trwało przez cały okres PRL. Było to jedno z zadań, jakie miały do wypełnienia telewizja, prasa czy radio. Stąd chętnie relacjonowano wszystko, co tylko mogło zaszkodzić obrazowi państw zachodnich w społeczeństwie polskim: problemy ekonomiczne, trudności gospodarcze, agresywna polityka zagraniczna, niepokoje społeczne, zabójstwa, morderstwa, katastrofy itp. Dotyczyło to zwłaszcza Stanów Zjednoczonych, które były

${ }^{18}$ Dr Martin L. King zamordowany, "Życie Warszawy”, 6 kwietnia 1968, s. 1; Stany Zjednoczone w ogniu rozruchów, "Życie Warszawy”, 7 kwietnia 1968, s. 1; Zamach na Roberta Kennedy'ego, "Życie Warszawy”, 6 czerwca 1968, s. 1-2; Robert Kennedy nie żyje, "Życie Warszawy", 7 czerwca 1968, s. 1; Francja w obliczu zaostrzajacego się kryzysu politycznego, „Trybuna Ludu”, 30 maja 1968, s. 1-2; V Republika na dnie, "Głos Szczeciński”, 30 maja 1968, s. 2. 
głównym, zwłaszcza ze względu na dużą sympatię i poparcie w społeczeństwie polskim dla wszystkiego co amerykańskie, negatywnym bohaterem. Jednak nie tylko. Kiedy tylko okoliczności na to pozwalały, przywoływano równie chętnie problemy innych państw zachodnich. Jedną z takich możliwości było skupianie się na „moralnym upadku Zachodu". Rozkwit narkomanii, permisywizm moralny, upadek kultury, czego dowodem miał być rozwój popkultury i popularność śmiałych i nierzadko skandalicznych produkcji filmowych, bunt młodych przeciwko światu dorosłych (nie wierzcie nikomu po trzydziestce) i jego instytucjom: rodzinie, Kościołowi, szkole, pracy, szefom, rywalizacji, pieniądzowi, wojsku, wojnie, normom, przymusom, zakazom (zakazuje się zakazywać), zanegowanie autorytetów i kryzys zaufania do instytucji społecznych i politycznych, emancypacja kobiet zagrażająca roli tradycyjnej rodziny, wzrost zachowań autodestrukcyjnych, tolerancja wobec rozwiązłości seksualnej, pornografii, homoseksualizmu, uważany był za totalny upadek moralny świata zachodniego ${ }^{19}$. Negatywnie oceniano subkultury młodzieżowe, takie jak: modsi, hippisi, metalowcy, punki i skinheadzi ${ }^{20}$. Szczególnie atakowano hippisów, ze względu na pojawienie się tej subkultury w Polsce ${ }^{21}$. Źródeł tych wszystkich negatywnych zjawisk upatrywano w wielu czynnikach, w tym właśnie w wydarzeniach i konsekwencjach roku 1968 na Zachodzie. Uważano bowiem, że wydarzenia roku 1968 dokonały głębokich, ocenianych negatywnie, zmian w świadomości zachodnich społeczeństw, a ówcześni studenci stają się teraz elitą społeczną i polityczną czy naukową w swoich krajach, co w konsekwencji nie może przynieść niczego dobrego. W takim przedstawianiu problemu zwraca uwage pewna niekonsekwencja oceny wydarzeń i następstw roku 1968. Następstwa, podobnie jak same wydarzenia, oceniane były negatywnie, ale negatywnie oceniano zarówno "stary porządek”, jak i działania państwa w celu stłumienia niezadowolenia protestujących ${ }^{22}$. Taka ocena „starego porządku” była usprawied-

${ }^{19}$ P.D. Zimmerman: op. cit., s. 25-27; Nostalgia za niegdysiejsza epoka wiktoriańska, „Forum”, 8 sierpnia 1977, nr 36, s. 23.

${ }^{20}$ Hippies, „Forum”, 25 czerwca 1967, nr 26, s. 18-19.

${ }^{21}$ N. Berland: O hippies źle i lepiej, „Forum”, 23 grudnia 1967, nr 52/53, s. 28.

${ }^{22}$ Bonn wprowadza stan wyjattkowy, „Forum”, 26 listopada 1967, nr 48, s. 6. 
liwieniem dla tych, którzy chcieli zmian, jednak równocześnie byli oni potępiani za swoje zachowanie. Ukazujące się teksty na temat zmian obyczajowych i stylu życia w państwach zachodnich były bardzo powierzchowne, nie miały na celu jakiejś głębszej analizy problemu, tylko najprostsze atakowanie państw zachodnich, w tym Niemiec.

\section{Terroryzm w Niemczech}

W 1977 roku doszło w RFN do poważnego kryzysu państwowego nazwanego Niemiecką Jesienią (Deutscher Herbst). Miało to związek $\mathrm{z}$ działalnością tzw. drugiej generacji RAF, która zamordowała najpierw nadzorującego śledztwo w sprawie przebywających w więzieniu liderów RAF-u prokuratora Bubacka, następnie w ramach tzw. Offensive 77 mordowali przedstawicieli niemieckiego biznesu, m.in. prezydenta Niemieckiego Związku Pracodawców (Bundesvereinigung der Deutschen Arbeitgeberverbände) Hannsa Martina Schleyera i prezesa Dresdener Bank Jürgena Ponto. RAF uzyskała wsparcie terrorystów palestyńskich, którzy porwali niemiecki samolot pasażerski, odbity następnie przez jednostkę antyterrorystyczną. W czasie tych wydarzeń przywódcy grupy popełnili, według oficjalnego komunikatu władz, samobójstwo.

Działalność RAF, lewicowej organizacji terrorystycznej, ideologicznie powiązanej z maoizmem, marksizmem, anarchizmem i nową lewica, nie zaczęła się w 1977 roku. Jednak w zasadzie do 1977 roku informacje na jej temat i na temat jej działalności nie pojawiały się w polskiej prasie. Pojedyncze teksty zamieszczono po zamachu bombowym w Heidelbergu na kwaterę główną armii amerykańskiej w Europie 24 maja 1972 roku, w której zginęło trzech żołnierzy amerykańskich. W kwietniu 1975 roku, kiedy RAF zaczęła okupację ambasady RFN w Sztokholmie, a po niespełnieniu jej żądań przez kanclerza RFN Helmuta Schmidta, zabiła dwoje zakładników, polska prasa informowała o tych wydarzeniach, ograniczając się jednak do oszczędnego przedstawiania faktów ${ }^{23}$,

\footnotetext{
${ }^{23}$ Napad na ambasade RFN w Sztokholmie, „Trybuna Ludu”, 25-27 kwietnia 1975, nr 95, s. 1.
} 
podobnie jak w przypadku zastrzelenia 7 kwietnia 1977 roku prokuratora generalnego Siegfrieda Bubacka ${ }^{24}$.

Sytuacja zmieniła się jesienią 1977 roku. 5 września 1977 roku członkowie RAF porwali prezydenta Niemieckiego Związku Pracodawców Hannsa Martina Schleyera, którego po 41 dniach przetrzymywania zamordowali. Od początku temat był dość obszernie relacjonowany w Polsce, właściwie codziennie pojawiały się informacje na temat porwanego, działań niemieckich władz w sprawie prób jego uwolnienia, żądań porywaczy, reakcji poszczególnych niemieckich polityków na akty terroru itp. ${ }^{25}$ Po porwaniu niemieckiego samolotu pasażerskiego i akcji jednostki terrorystycznej na lotnisku w Mogadiszu ${ }^{26}$, samobójstwie przywódców $\mathrm{RAF}^{27}$ i zamordowaniu Hannsa Schleyera ${ }^{28}$ polska prasa baczniej zaczęła się przyglądać temu, co działo się w RFN. Z jednej strony skupiano

${ }^{24}$ Zamach na prokuratora generalnego RFN, „Trybuna Ludu”, 9-11 kwietnia 1977, nr 84, s. 1-2.

${ }^{25}$ Porwanie Schleyera, "Forum”, 15 września 1977, nr 37, s. 6-7; Porywacze żądaja uwolnienia terrorystów, „Trybuna Ludu”, 8 września 1977, nr 212, s. 2; Żadania porywaczy Schleyera wobec władz, "Trybuna Ludu”, 9 września 1977, nr 213, s. 2; Władze przejęty taktykę «elastycznej nieustępliwości», „Trybuna Ludu”, 10 września 1977, nr 214, s. 2; Tajemnica otacza pertraktacje władz z terrorystami, „Trybuna Ludu”, 12 września 1977, nr 215, s. 2; Terroryści gotowi do negocjacji, „Trybuna Ludu”, 13 września 1977, nr 216, s. 2; Rząd boński kontynuuje wysitek zmierzajacy do uwolnienia H. Schleyera, „Trybuna Ludu”, 19 września 1977, nr 221, s. 1; Rząd RFN próbuje rozwiazać sprawę Schleyera, „Trybuna Ludu”, 22 września 1977, nr 224, s. 2; Nowe oznaki życia H.M. Schleyera, "Trybuna Ludu”, 26 września 1977, nr 227, s. 2; Czy Schleyer zostat wywieziony za granice??, "Trybuna Ludu”, 28 września 1977, nr 229, s. 2; Schleyer uwięziony na jachcie u wybrzeży duńskich?, „Trybuna Ludu”, 30 września 1977, nr 231, s. 1-2; Kolejne posiedzenie «sztabu kryzysowego» w sprawie Schleyera, „Trybuna Ludu”, 4 października 1977, nr 234, s. 2; List Schleyera do redakcji dwóch dzienników paryskich, „Trybuna Ludu”, 10 października 1977, nr 239, s. 2; Sprawa Schleyera bez goraczki, „Forum”, 13 października 1977, nr 41, s. 7.

26 Scenariusz pisany krwia, „Forum”, 20 października 1977, nr 42, s. 4-5; Uprowadzony samolot wyladowat w Dubaju, „Trybuna Ludu”, 15-16 października 1977, nr 244, s. 1-2; Porwany samolot RFN wyładowat w Adenie, „Trybuna Ludu”, 17 października 1977, nr 245, s. 1-2; Dramatyczny los pasażerów samolotu «Lufthansy», „Trybuna Ludu”, 18 października 1977, nr 246, s. 1-2; Pasażerowie uwolnieni - trzech porywaczy nie żyje, "Trybuna Ludu", 19 października 1977, nr 247, s. 1-2.

${ }^{27}$ Czwórka z siódmego piętra, „Polityka”, 29 października 1977, nr 44, s. 11; Nadal znaki zapytania wokót śmierci terrorystów w więzieniu stuttgarckim, „Trybuna Ludu”, 27 października 1977, nr 254, s. 2; Pogrzeb terrorystów w Stuttgarcie, „Trybuna Ludu”, 28 października 1977, nr 255, s. 2.

${ }^{28}$ Teraz cię zastrzelę, „Polityka”, 29 października 1977, nr 44, s. 12-13; H. M. Schleyer nie żyje, „Trybuna Ludu”, 20 października 1977, nr 248, s. 1, 9. 
się na kryzysie państwa, co było zgodne wytycznymi dla prasy, w jakim znalazła się RFN jesienią 1977 roku, tzw. Deutscher Herbst, z drugiej strony coraz większe zainteresowanie samym terroryzmem, jego przyczynami powodowało, iż starano się zgłębiać to, co stało się w Niemczech i dlaczego akurat w tym kraju ${ }^{29}$.

Pojawiły się teksty podejmujące próbę wyjaśnienia i analizy opisanych powyżej wydarzeń. Wskazywano, że grupa wyrosła z fali niepokojów młodzieżowo-studenckich, które miały miejsce w 1968 roku. Przypominano zabójstwo Benno Ohnesorga podczas rozbicia przez zachodnioniemiecką policję demonstracji przeciwko wizycie w Berlinie Zachodnim dyktatora Iranu szacha Rezy Pahlawiego w 1967 roku oraz próbę zabójstwa Rudiego Dutschkego przez Josepha Bachmanna w 1968 roku. Wskazywano, że członkowie RAF kwestionowali powierzchownie rozliczoną narodowosocjalistyczną przeszłość Niemiec (co było okazją do kolejnych tekstów na temat nazizmu w Niemczech, II wojny światowej, przeszłości niektórych niemieckich polityków), amerykański imperializm i wojnę w Wietnamie (co dawało pretekst do przypomnienia agresywnej amerykańskiej polityki zagranicznej), dążyli do obalenia systemu kapitalistycznego w Republice Federalnej Niemiec, wspierali ruchy narodowo-wyzwoleńcze w Trzecim Świecie, podkreślano ich związek z tzw. Opozycją Pozaparlamentarną i kontrkulturową Komuną I. Podkreślano te, które w złym świetle stawiały politykę Niemiec, państw Europy Zachodniej, uderzały w kapitalizm, zachodni styl życia ${ }^{30}$. $\mathrm{W}$ związku z tym przywoływano opinie, że to samo społeczeństwo industrialne sprowokowało własne - od wewnątrz - zniszczenie poprzez systematyczne pozbawianie władzy i poddawanie jednostki prawom rynku oraz ogołacanie życia z jakiejkolwiek treści. Korzenie terroryzmu

\footnotetext{
${ }^{29}$ Bonn po szoku, „Forum”, 3 listopada 1977, nr 44, s. 8-9; Miałem wszelkie petnomocnictwa, „Polityka”, 29 października 1977, nr 44, s. 12; Partie polityczne w Bundestagu potępiaja akty terroru, „Trybuna Ludu”, 16 września 1977, nr 219, s. 2; R. Drecki: Mroki terroryzmu, „Trybuna Ludu”, 17 października 1977, nr 245, s. 2; Prawica w RFN wykorzystuje walkę z terroryzmem dla swoich celów, „Trybuna Ludu”, 22-23 października 1977, nr 250, s. 1-2; Wielka akcja policji na razie bez rezultatów, „Trybuna Ludu”, 24 października 1977, nr 251, s. 1-2; Wielki pościg za terrorystami, „Trybuna Ludu”, 25 października 1977, nr 252, s. 1-2; Trwa obława na terrorystów, „Trybuna Ludu”, 26 października 1977, nr 253, s. 1, 9.

${ }^{30}$ W. Giełżyński: Bez psychozy, „Polityka”, 29 października 1977, nr 44, s. 13; H. Zdanowski: Jeśli spełnicie warunki, „Polityka”, 24 września 1977, nr 39, s. 10-12.
} 
widziano w ruchu studenckim 1968 roku, a samego ruchu w subkulturach młodzieżowych, które poszukują innej drogi i przeciwstawiają się ustalonym zachowaniom, tradycjom, instytucjom i autorytetom. $Z$ jednej strony wskazywano, że młodzi w Niemczech mogą dużo, a nawet pozwalano im na zbyt wiele, $z$ drugiej wskazywano na bezrobocie, niski poziom edukacji, szerzące się uzależnienia ${ }^{31}$. Powtarzano opinie pojawiające się w prasie niemieckiej i europejskiej, że terroryzm jest konsekwencją niemieckiego cudu gospodarczego i brutalności niemieckiego systemu. Wydarzenia w RFN i związki RAF-u z innymi organizacjami terrorystycznymi, m. in. Czerwonymi Brygadami, były okazją do szerszego omawiania terroryzmu, skupiania się nie tylko na RFN, ale przywoływania też przykładów z innych państw europejskich ${ }^{32}$.

\section{Joschka Fischer ministrem spraw zagranicznych RFN}

27 października 1998 roku Joseph Martin Fischer, jeden z liderów niemieckiej partii Związek 90/Zieloni, został mianowany ministrem spraw zagranicznych oraz wicekanclerzem w rządzie Gerharda Schrödera $^{33}$. Ze względu na jego życiorys fakt ten stał się pretekstem do przypomnienia wydarzeń roku 1968 w Niemczech. Jednak skupiono się na samym przypominaniu zdarzeń sprzed 30. lat, często w stylu „taniej sensacji”, mniej lub bardziej bezpośrednio wyrażając swoje zdziwienie, że polityk o takiej przeszłości może piastować stanowisko ministra spraw zagranicznych Niemiec, choć nie brakowało też opinii o pewnej ironii losu i oczekiwań wobec nowego wicekanclerza. Wskazywano, że jest to kariera bez precedensu - „dawny włóczęga, rebeliant żyjący na marginesie społeczeństwa, który rzucał kamieniami w policjantów i walczył na barykadach - szefem niemieckiej dyplomacji".

Joschka Fischer został bowiem w 1967 roku aktywistą niemieckiego ruchu studenckiego, który organizował protesty na ulicach niemieckich miast, a także w latach 1968-1975 był członkiem skrajnie lewicowej

${ }^{31}$ Pokolenie zbędnych, "Forum”, 11 sierpnia 1977, nr 32, s. 6-7; Gdzie sa kwiaty z tamtych lat?, „Forum”, 6 października 1977, nr 40, s. 20-21; H. Zdanowski: Dlaczego właśnie RFN?, „Polityka”, 12 listopada 1977, nr 46, s. 10-11.

${ }^{32}$ M. Jaranowski: Za scena terroru, „Polityka”, 5 listopada 1977, nr 45, s. 12.

${ }^{33}$ Skrzydła Gerharda, „Polityka”, 24 października 1998, nr 43, s. 38-43. 
organizacji Walka Rewolucyjna (Revolutionärer Kampf). Bettina Röhl w swojej książce So macht Kommunismus Spass! ${ }^{34}$ zarzuciła mu pomoc terrorystom z RAF oraz napaść na policjantów podczas zamieszek, co było powodem kilkukrotnego przesłuchiwania Fischera przez prokuraturę. To właśnie takie wydarzenia cieszyły się zainteresowaniem prasy. Do tego należy jeszcze dodać poparcie przez Fischera jako szefa niemieckiej dyplomacji interwencji wojsk $w$ rejonie Bałkanów oraz w Afganistanie $\mathrm{w}$ związku z zamachami na Nowy Jork i Waszyngton 11 września 2001 roku, co mijało się nie tylko z pierwotnymi celami partii Zielonych i jej pacyfistycznym nastawieniem do wszelkich konfliktów, ale także z poglądami samego Joschki Fischera w latach sześćdziesiątych i siedemdziesiątych ${ }^{35}$. Poważniejszych opracowań tym razem również zabrakło.

\section{Inne aspekty obrazu Niemca i Niemców w prasie polskiej}

Rok 1968 w Niemczech, jak już stwierdziłam, nie budził większego zainteresowania polskich mediów ze względu na ",atrakcyjniejsze” wydarzenia w innych państwach zachodnich, przede wszystkim w Stanach Zjednoczonych i we Francji, które dawały się wykorzystywać propagandowo. Odniesień do roku 1968 w Niemczech w następnych latach też jest niedużo. Bowiem wszędzie tam, gdzie tylko było możliwe, dziennikarze odnosili się do tematu II wojny światowej. Działo się tak, jak już wspomniałam, nawet w stosunku do samych wydarzeń roku 1968, kiedy więcej miejsca poświęcano ustawom wyjątkowym - odnosząc ich wprowadzenie do roku 1933, a nie temu, co działo się na ulicach niemieckich miast.

Tematyka niemiecka gościła więc na łamach polskiej prasy stosunkowo często, jednak zazwyczaj ustępowała, co nie powinno dziwić, tematom związanym ze Związkiem Radzieckim, Stanami Zjednoczonymi i zazwyczaj, choć nie zawsze, z Francją. Tematy radzieckie do tego stopnia przeważały, że nawet parafowanie układu Polska-RFN w li-

${ }^{34}$ Wydanie polskie B. Röhl: Zabawa w komunizm! Ulrike Meinhof, Klaus Rainer Röhl i prawdziwe korzenie nowej lewicy (1958-1968), Warszawa 2007.

${ }^{35}$ K. Keciek: Maratończyk Joschka Fischer, „Przegląd” 2003, nr 28, dostęp online 1 grudnia 2010. 
stopadzie 1970 roku, przegrało z relacją o radzieckim automatycznym pojeździe księżycowym „Łunochod”, który w swojej księżycowej wędrówce realizował badania naukowo-techniczne. Wprawdzie 19 listopada $\mathrm{w}$ większości gazet obydwa te tematy znalazły się na pierwszych stronach, ale informacja o kolejnym sukcesie radzieckiej nauki w podboju kosmosu, do której załączono jeszcze gratulacje w imieniu Komitetu Centralnego Polskiej Zjednoczonej Partii Robotniczej, Rady Państwa, rządu oraz narodu polskiego, zajmowała zdecydowanie więcej miejsca ${ }^{36}$.

Dużo miejsca prasa poświęcała rocznicom związanym z II wojną światową: jej początkiem i zakończeniem, rocznicom wyzwolenia obozów, pacyfikacjom, rozstrzeleniom itp.; oprócz relacji z przebiegu uroczystości w Polsce pojawiały się przypomnienia i odwołania do samej wojny, tragiczne relacje świadków, przypomnienia o skali zbrodni, czasami zdjęcia $\mathrm{z}$ tamtego okresu. Zazwyczaj tematy te zestawiano $\mathrm{z}$ niemieckimi oczekiwaniami przeprosin za wypędzenia, wypowiedziami kwestionującymi granicę na Odrze i Nysie Łużyckiej itp. ${ }^{37}$ Żywo i bardzo emocjonalnie przekazywano informacje dotyczące partii neofaszystowskiej, uczczenia jakieś rocznicy w Niemczech związanej z II wojną światową czy polityką tamtych czasów. Z niepokojem relacjonowano wypowiedzi niemieckich polityków, jeśli w ich przemówieniach pojawiło się nieodpowiednie odniesienie do przeszłości. Ostrzegano przed niemieckim rewanżyzmem i relatywizmem, wskazując, że Niemcy cały czas mogą stanowić zagrożenie (pojawiała się tu zazwyczaj kwestia zachodniej granicy Polski) i że za II wojnę nie dość przepraszają ${ }^{38}$, że w RFN propagowane jest niewłaściwe spojrzenie na historie najnowszą cechujące się „niedostateczną świadomością historyczną”, retuszowaniem wszelkich akcentów ponurych i zbrodniczych oraz szukaniem

${ }^{36}$ Parafowanie uktadu Polska-NRF, „Trybuna Ludu”, 19 listopada 1970, nr 322, s. 1-2; tamże «Łunochod 1» kontynuuje eksperyment na Księżycu", s. 1; Parafowanie układu Polska-RFN, „Ilustrowany Kurier Polski”, 19 listopada 1970, nr 275, s. 1-2; tamże „Eunochod zakończył pierwszy etap księżycowej wędrówki", s. 1-2.

37 A TVP, sygn. 3118 (bez tytułu); Dla uznania granicy, „Trybuna Ludu”, nr 302, s. 2; Memorandum Bensberger Kreis, „Polityka”, 16 marca 1968, nr 11, s. 9; M.F. Rakowski: My i Niemcy, „Polityka”, 16 sierpnia 1969, nr 33, s. 1, 8-9; A. Krzemiński: Czy przepraszać Niemców?, „Polityka”, 1 września 1990, nr 35, s. 1, 6.

${ }^{38}$ Po faszystowskiej prowokacji w Berlinie, „Trybuna Ludu”, nr 312, s. 1; H. Harting: op. cit., s. 8. 
okoliczności łagodzących przy ignorowaniu faktów ${ }^{39}$. Duże obawy budziło także odradzanie się armii niemieckiej ${ }^{40}$.

Na przestrzeni wszystkich tych lat stosunkowo dużo miejsca poświęcano niemieckiej scenie politycznej, interesując się poszczególnymi wyborami: prezydenckimi, parlamentarnymi, do Landtagów. Jednak teksty były mało analityczne, skupiały się raczej na podaniu samej informacji, ewentualnie podkreślały problemy na niemieckiej scenie politycznej, kłótnie, brak zgody. Autorzy (po 1990 roku) zastanawiali się w okresie kampanii, który kandydat będzie najlepszy z polskiego punktu widzenia i stosunków polsko-niemieckich. Bardzo krytycznie przyglądano się kandydatom i nowo wybranym pod kątem ich stosunku do historii, II wojny światowej, relacjom najpierw z blokiem wschodnim, potem z Europą Środkowo-Wschodnią i samą Polską ${ }^{41}$. Szeroko relacjonowano też wizyty polityków niemieckich w Polsce i polskich w Niemczech ${ }^{42}$.

Wydarzeniem, które skupiło szczególną uwagę polskich mediów, był upadek muru berlińskiego. Wiele tytułów zamieściło obszerne relacje pełne wypowiedzi szczęśliwych Berlińczyków. Tekstom towarzyszyły zdjęcia ${ }^{43}$. Jednak samemu zjednoczeniu Niemiec część prasy nie poświęciła zbyt wiele uwagi. Teksty były chłodne, przekazujące tylko najważniejsze informacje, zazwyczaj były ukryte gdzieś między innymi tekstami. Na przykład w "Ilustrowanym Kurierze Polskim” temat ten, choć znalazł się na pierwszej stronie, zajmuje tylko kilka linijek, „przegrywając” z innymi, takimi jak: "Zapowiada się ostra debata mieszkaniowa w Sejmie”, ,NNastroje społeczne we wrześniu”, ,Inauguracja roku

\footnotetext{
${ }^{39}$ Nowe mapy pojawiaja się w NRF, „Ilustrowany Kurier Polski” 1970, nr 268, s. 1; N. Honsza: Podręczniki potomków Niebelungów, „Polityka”, 24 czerwca 1972, nr 26, s. 1, 10.

${ }^{40}$ A. Skowroński: Duch i siła kasty, „Polityka”, 18 lipca 1970, nr 29, s. 10.

${ }^{41}$ Jak chadecja walczy o władzę, "Trybuna Ludu” 1970, nr 317, s. 1, 7; H. Zdanowski: Koalicyjne gry i zabawy, "Polityka”, 15 stycznia 1977, nr 3, s. 1, 11; Prasa o nowej koalicji, „Polityka”, 18 października 1969, nr 42, s. 9; M.F. Rakowski: Sprawa Polska nad Renem, „Polityka”, 5 lutego 1972, nr 6, s. 9-11; idem: Godzina decyzji, „Polityka”, 11 września 1972 , nr 46, s. 1, 5-11; A. Krzemiński: Kandydat ze wschodu, „Polityka”, 23 października 1993, nr 43, s. 1; idem: Pomyst na Niemcy, „Polityka”, 20 stycznia 1990, nr 3, s. 1; idem: M.F. Rakowski, H. Zdanowski: «Niemiecka partia rzadzaca», „Polityka”, 7 czerwca 1968, nr 23, s. 1, 7-12.

${ }^{42}$ APR, sygn. 5548 poz. 3, 7 dni w kraju i na świecie.

${ }^{43}$ Berliński mur przechodzi do historii, "Ilustrowany Kurier Polski” 1989, nr 263, s. 1; M. Regel: Noc pełna szczęścia, „Polityka”, 18 września 1989, nr 46, s. 12.
} 
na bydgoskiej Akademii Medycznej” ${ }^{\prime 4}$. Kilka dni później pojawiało się jednak sporo artykułów rozważających wpływ zjednoczenia Niemiec na Polskę. W tekstach, pozbawionych nuty alarmistycznej, histerycznej, tak charakterystycznej dla wcześniejszego ustroju, pojawiają się jednak obawy związane ze zbyt silnym sąsiadem z Zachodu, przez którego Polska już tyle doświadczyła. W niektórych opracowaniach pojawia się także nadzieja, że zjednoczone Niemcy będą miały większe znaczenie w Europie i na świecie, a to może być korzystne dla Polski, zwłaszcza w kontekście przystąpienia do EWG i NATO, skoro kraj ten popiera polskie aspiracje. Na tym tle wyróżnia się "Polityka”, gdzie temat ten, oprócz tego, że znalazł się na pierwszych stronach, to doczekał się kilku rzetelnych opracowań. Zwrócić należy jednak uwagę, że teksty ukazały się z opóźnieniem w stosunku do samych wydarzeń ${ }^{45}$. Trzeba jeszcze zaznaczyć, że przez wszystkie lata poprzedzające zjednoczenie Niemiec bano się tego możliwego wówczas wydarzenia. Nie tylko ze względu na ich ewentualny wpływ na Polskę, ale też z uwagi na NRD, gdzie „przemiany i osiągnięcia należą do kategorii tych przeobrażeń, które wrosły już w nowa glebę i usunąć się nie dadzą" ${ }^{46}$.

W przeciagu całego analizowanego okresu media polskie bardzo chętnie podawały informację o problemach i kłopotach i to nieważne jakich, byle były: czy to upadek rządu, problemy gospodarcze, terroryzm, jakieś wyskoki młodzieży, przegrana niemieckiej reprezentacji narodowej w piłkę nożną czy "tylko" srebrny medal na olimpiadzie (zwłaszcza jeśli złoto zdobył ktoś z bloku wschodniego ${ }^{47}$. W tekstach prasowych do 1989 roku ta chęć niekorzystnego przedstawiania RFN jest bardzo widoczna, w późniejszych latach już nie tak bezpośrednia, jednak w części tytułów nadal czytelna.

44 "Ilustrowany Kurier Polski”, 4 października 1990, nr 230, s. 1.

${ }^{45}$ Poczatek przełomu w naszych stosunkach, "Ilustrowany Kurier Polski”, 13 listopada 1989, nr 262, s. 1-2; A. Krzemiński: Nasz nowy, stary sąsiad, „Polityka”, 13 października 1990, nr 41, s. 1, 12.

${ }^{46}$ Inwazja, "Polityka”, 7 czerwca 1969, nr 23, s. 10; M. Podkowiński: Boński koszmar, „Polityka”, 17 lipca 1968, nr 33, s. 10; Pokój w Europie nie jest zagrożony, „Polityka”, 19 marca 1977, nr 12, s. 1, 12; M.F. Rakowski: Dwa państwa niemieckie, „Polityka”, 31 stycznia 1970 , nr 5, s. 8.

${ }^{47}$ M.F. Rakowski: Kryzys w Bonn, „Polityka”, 20 maja 1972, nr 21, s. 1, 5-11; T. Drewnowski: Burza nad Renem, „Polityka”, 6 maja 1972, nr 19, s. 1, 4, 8. 
Obraz wydarzeń kreowany w polskich mediach miał odpowiadać założeniom propagandowym i polskiej polityce zagranicznej. Dlatego też nie był rzetelny, wiarygodny, tylko zmanipulowany, „przefiltrowany" przez cenzurę, często uzupełniony odpowiednim komentarzem, aby odbiorca wiedział, co ma myśleć. W Polskiej Rzeczpospolitej Ludowej obraz ten był schematyczny. We wszystkich codziennych tytułach prasowych zazwyczaj ukazywała się taka sama lub prawie taka sama informacja, jeśli dołączone było do niej zdjęcie, to zazwyczaj to samo, podobnie rzecz się miała z komentarzami. Często brakowało poważnych analiz i rzetelnych opinii oraz komentarzy. Sytuacja zmieniła się dopiero po 1989 roku. Obraz Niemca w prasie polskiej do tego czasu to przede wszystkim obraz rewanżysty, rewizjonisty, przekłamującego historię i pałającego ukrytą (mniej lub bardziej, a czasami wcale) sympatią do czasów hitlerowskich. Niemiec taki ciągle stanowił zagrożenie dla Polski i Polaków, zwłaszcza w kontekście polskiej granicy zachodniej. Ton ten trochę złagodniał $\mathrm{w}$ latach siedemdziesiątych, ale obaw przed Niemcami nie udało się pozbyć. Widać to szczególnie w relacjach dotyczących zjednoczenia Niemiec, a także późniejszych tekstach przedstawiających siłę Niemiec, zwłaszcza ekonomiczną, na arenie międzynarodowej, w Unii Europejskiej. Stąd obraz niemieckiego roku 1968 $\mathrm{w}$ polskich mediach skupia się przede wszystkim na wprowadzeniu ustaw wyjątkowych, tłumieniu protestów i brutalności policji oraz krytykowaniu sytuacji w Niemczech, która do tego doprowadziła. Samym wydarzeniom, poza zamachem na Rudiego Dutschkego, nie poświęcono więcej uwagi, wpisując protesty studenckie w Niemczech w ciąg podobnych wydarzeń w innych państwach zachodnich w tym czasie. Podobnie jest $\mathrm{w}$ latach następnych odniesień do 1968 roku jest niewiele, przeważają bowiem odniesienia do II wojny światowej. Rok 1968 traktowany jest głównie jako przyczyna i wyjaśnienie wszystkiego, co złe i niemoralne w sferze obyczajowej, społecznej, moralnej, a więc takich zjawisk (wszystkich ocenianych negatywnie) jak subkultury młodzieżowe, feminizm, upadek tradycyjnej rodziny, wolność seksualna, narkomania, upadek szkolnictwa, terroryzm itp. Po nominacji Joschki Fische- 
ra na stanowisko ministra spraw zagranicznych Niemiec wydarzenia 1968 roku powracają na łamy prasy polskiej, jednak w formie "taniej sensacji".

\section{Abstract \\ Polish public opinion toward Germany and the events of 1968 in that country}

The media system formed in Poland after the Second Word War was subordinated to political practice. The ruling communist party treated the radio, press and television as one of the most important tools for exercising power and controlling social processes. All the content being conveyed was scrupulously censored. The same applied to articles concerning the Federal Republic of Germany. Throughout the entire era of the People's Republic of Poland, the RFG was 'the villain of the piece'. The press published numerous articles in reminder of the Second World War and successive anniversaries of specific crimes, incessantly recalling their scale, the destruction and the number of victims. The texts frequently referred to the revisionist policy of the post-war RFG. West Germany was thus presented as a militaristic state, striving to obtain nuclear weapons and rockets, exerting pressure on her Western partners to push armament programmes and frustrating disarmament, a state where the left was suppressed and the German Communist Party was persecuted by the police while the Nazis (NDP) grew in strength. In view of Bonn's obsession with regard to the re-unification of Germany, Poland, went the narrative, could not trust West Germany. Such an image of the RFG in the Polish media was congruent with the objectives of Poland's foreign policy toward that country.

In 1968, the events occurring in the FRG, the youth's protest on a mass scale, the brutal methods of the police, the passing of emergency laws which restricted citizens' freedoms, were reported accurately, emotionally and with a propaganda bias. These reports were given an additional emphasis by their tone, which was alarmist, often hysterical and with no shortage of loaded headlines, which usually made reference to the Second World War and the perpetual threat posed to both Poland and the other Eastern Bloc states by the FRG. There were few references in the Polish press to 1968 in Germany. They were recalled, in principle, only when criticising the Western life style and the 'moral collapse of the West', reporting terrorism-related events in Germany, in particular, the Red Army Faction in the 1970s and the appointment of Joschka Fischer as foreign minister of the FRG in 1998. On the other hand, mention was frequently made of the events related to the Second World War, associating them with the German expectations of apologies for the expulsions, statements putting a question mark over the Oder and Lusitian Neisse rivers, and so forth. Throughout these years, a relatively considerable 
amount of column space was devoted to the German political scene, expressing interest in particular elections. In the entire period analysed here, the Polish media were very eager to report German problems and troubles such as the titles. the fall of a government, economic woes, terrorism, the excesses of the young people, the defeat of Germany's national football team, or the FRG's 'only' winning a silver medal in the Olympics. Pre-1989, this willingness to pesent the FRG unfavourably is highly visible; later it becomes less direct, though it can still be perceived in some of the titles. 